\section{Perlindungan Hukum Bagi Konsumen Muslim Terhadap Peredaran Makanan Tidak Bersertifikat Halal (Studi pada LPPOM MUI Sumatera Utara di Medan)"}

\author{
Oleh: \\ Hj. Masnun ${ }^{1}$
}

\section{Abstract}

The regulations for legal protection for Muslim consumers against the circulation of not halal food certified are regulated in the Law of the Republic of Indonesia Number 18 of 2012 concerning Food and the Law of the Republic of Indonesia Number 8 of 1999 concerning Consumer Protection, the Law of the Republic of Indonesia Number 33 of 2014 concerning Halal Product Guarantee.

The role of $L P P O M M U I$ in halal certification is as $L P H$ where $L P P O M$ will be an institution that carries out the process of inspecting food ingredients, inspecting product processing, examining equipment, production rooms, and checking the halal assurance system. In addition, the role of $\angle P P O M M U I$ as $L P H$ is to submit the results of the inspection and / or testing the halalness of the product to BPJH.

\section{Keywords: Legal Protection, Muslim Consumers, Food Circulation, Not Halal Certified.}

\begin{abstract}
Abstrak
Pengaturan perlindungan hukum bagi konsumen muslim terhadap peredaran makanan tidak bersertifikat halal di atur dalam UndangUndang Republik Indonesia Nomor 18 Tahun 2012 tentang Pangan dan Undang-Undang Republik Indonesia Nomor 8 Tahun 1999 tentang Perlindungan Konsumen, UndangUndang Republik Indonesia Nomor 33 Tahun 2014 tentang Jaminan Produk Halal.
\end{abstract}

Peranan LPPOM MUI dalam sertifikasi halal adalah sebagai LPH dimana LPPOM akan menjadi lembaga yang melakukan proses pemeriksaan bahan makanan, memeriksa pengolahan produk, meneliti peralatan, ruang produksi, serta memeriksa sistem jaminan

\footnotetext{
${ }^{1}$ Dosen Fakultas Hukum UISU
}

halal.Selain itu peran dari LPPOM MUI sebagai LPH adalah menyerahkan hasil pemeriksaan dan/atau pengujian kehalalan produk kepada BPJH

Kata Kunci : Perlindungan Hukum, Konsumen Muslim, Peredaran Makanan, Tidak Bersertifikat Halal.

\section{PENDAHULUAN}

\section{A. Latar Belakang}

Hukum perlindungan konsumen dewasa ini mendapat cukup perhatian karena menyangkut aturan-aturan guna mensejahterakan masyarakat, bukan masyarakat selaku konsumen saja yang mendapat perlindungan, namun pelaku usaha juga mempunyai hak yang sama untuk mendapat perlindungan, masing-masing mempunyai hak dan kewajiban. Pemerintah berperan mengatur, mengawasi, dan mengontrol sehingga tercipta sistem yang kondusif saling berkaitan satu dengan yang lain dengan demikian tujuan mensejahterakan masyarakat secara luas dapat tercapai. ${ }^{2}$

Pengetahuan tentang hukum makanan yang halal sangat penting bagi kehidupan konsumen muslim, karena berhubungan dengan hajat manusia setiap waktu. Dengan adanya label halal dalam suatu produk makanan maka konsumen muslim dapat memastikan produk mana saja yang boleh dikonsumsi. Sesuai dengan Pasal 4 Undang-Undang Republik Indonesia Nomor 33 Tahun 2014 Tentang Jaminan Produk Halal (Selanjutnya disebut UU Jaminan Produk Halal) menyatakan

${ }^{2}$ Celina Tri Siwi Kristiyanti, Hukum Perlindungan Konsumen, Sinar Grafika, Jakarta, 2018, h.1. 
Media Komunikasi dan Informasi Hukum dan Masyarakat

bahwa,Produk yang masuk atau beredar dan diperdagangkan di wilayah Indonesia wajib bersertifikat halal.

Data dari Lembaga Pengkajian Pangan, Obat-Obatan dan Kosmetika Majelis Ulama Indonesia (LPPOM MUI) Sumatera Utara di Medan pada tahun 2019,terdaftar 286 jumlah produk dan jumlah sertifikat halal yang terdapat pada LPPOM MUI Sumut di Medan, dan terdaftar 243 jumlah perusahaan/pelaku usaha yang mendaftarkan produk makanannya ke LPPOM MUI Sumut di Medan.

Beberapa kasus maraknya peredaran label halal palsu disebabkan kurangnya pengetahuan dari pengusaha, meski tindakan tersebut salah. Selain itu, pengusaha tidak siap untuk melalui tahapan memperoleh sertifikat halal, seperti kesiapan dokumen hingga produksinya.Dampaknya, mereka tak lolos saat audit. Seperti dalam contoh kasus dua varian mi instan asal Korea yang didalamnya mengandung unsur babi seperti dalamSamyang,Nongshim, dan Ottogi, ${ }^{3} \mathrm{Mie}$ Instan Jajangmyeon Korea yang belum memiliki sertifikat halal, dua produk dairy milk yang mengandung unsur babi yaitu cadbury dairy milk roast almond dan cadbury milk hazelnut dan produk makanan Pringles belum bersertifikat halal MUI.

Konsumen merupakan golongan yang rentan dieksploitasi oleh pelaku usaha. Karena itu, diperlukan seperangkat aturan hukum untuk melindungi konsumen. ${ }^{4}$ Berhubung dengan hal ini, pemerintah mempunyai peran penting terhadap sertifikasi dan labeling halal dibutuhkan dalam suatu produk makanan

${ }^{3}$ https://www.islampos.com/ylki-sumutimbau-masyarakat-waspadai-peredaran-mi-instanmengandung-babi-53528/, diakses pada tanggal 2 Juli 2019, pukul $8.23 \mathrm{Wib}$.

4 Munir Fuady, Pengantar Hukum Bisnis, Citra Aditya Bakti, Bandung,2016,h.227. karena sebagai konsumen muslim dibutuhkan sebuah informasi yang jelas terhadap makanan yang bersertifikat halal karena menjadi sebab, mana makanan yang dapat dikonsumsi dengan baik (thayyiba) dan mana makanan yang tidak dapat dikonsumsi. Pemerintah juga dituntut untuk melakukan upaya perlindungan hukum guna melindungi konsumen muslim dalam hal sertifikasi halal suatu produk makanan.

Lembaga Pengkajian Pangan, Obatobatan, dan Kosmetika Majelis Ulama Indonesia atau yang disebut LPPOM MUI adalah lembaga yang bertugas kuat untuk meneliti, mengkaji, menganalisis dan memutuskan apakah produkproduk baik pangan dan turunannya, obatobatan dan produk kosmetika apakah aman dikonsumsi baik dari sisi kesehatan dan dari sisi ajaran agama Islam yakni halal atau boleh dan baik untuk dikonsumsi bagi umat Muslim khususnya di wilayah Indonesia, selain itu memberikan rekomendasi, merumuskan ketentuan dan bimbingan kepada layanan masyarakat. $^{5}$

\section{B. Rumusan Masalah}

Berdasarkan dari latar belakang yang telah diuraikan, maka penulis merumuskan masalah yang akan diteliti adalah sebagai berikut:

1. Bagaimana perlindungan hukum bagi konsumen muslim terhadap peredaran makanan yang tidak bersertifikat halal di Kota Medan?

2. Bagaimana peran Lembaga Pengkajian Pangan Obat-obatan dan Kosmetika Majelis Ulama Indonesia (LPPOM MUI) dalam hal pengawasan dan memberikan

5 https://id.wikipedia.org/wiki/LPPOM_MUI diakses pada tanggal 2 Juli 2019 Pukul $11.00 \mathrm{Wib}$ 
Media Komunikasi dan Informasi Hukum dan Masyarakat

kepastian hukum terhadap masyarakat di Kota Medan?

\section{Tujuan Penelitian}

Adapun tujuan dari penelitian ini adalah:

1. Untuk mengetahui pengaturan sertifikasi halal terhadap makanan.

2. Untuk mengetahui perlindungan hukum bagi konsumen muslim terhadap peredaran makanan yang tidak bersertifikat halal.

3. Untuk mengetahui peran Lembaga Pengkajian Pangan Obat-obatan dan Kosmetika Majelis Ulama Indonesia (LPPOM MUI) dalam hal pengawasan dan memberikan kepastian hukum terhadap masyarakat di Kota Medan.

\section{Manfaat Penelitian}

Disamping tujuan yang hendak dicapai sebagaimana yang dikemukakan diatas, maka penulisan skripsi ini juga memberikan manfaat baik secara teoritis maupun secara praktis.

1. Manfaat Teoritis

a. Skripsi ini diharapkan memberikan sumbagan pemikiran pengembangan bidang pengetahuan hukum umumnya maupun hukum perdata khususnya sehingga dapat menambah bahan referensi dan bahan masukan untuk penelitian selanjutnya.

b. Skripsi ini diharapkan dapat memberikan gambaran umum tentang bentuk perlindungan konsumen muslim terhadap makanan bersertifikat/berlabel halal serta menjadi bahan masukan bagi masyarakat umum dan aparat penegak hukum untuk memberikan perlindungan konsumen terhadap konsumen muslim atas makanan bersertifkat halal.

2. Manfaat Praktis
Secara praktis hasil penelitian ini dapat memberikan masukan dalam perkembangan ilmu hukum, khususnya yang berhubungan dengan masalah perlindungan hukum konsumen muslim terhadap makanan yang tidak bersertifikat halal.

\section{E. Definisi Operasional}

1. Perlindungan Hukum adalah perlindungan akan harkat dan martabat, serta pengakuan terhadap hak-hak asasi manusia yang dimiliki oleh subyek hukum berdasarkan ketentuan hukum dari kesewenangan. ${ }^{6}$

2. Perlindungan konsumen adalah segala upaya yang menjamin adanya kepastian hukum untuk memberi perlindungan kepala konsumen.

3. Konsumen adalah setiap orang pemakai barang dan/atau jasa yang tersedia dalam masyarakat, baik bagi kepentingan diri sendiri, keluarga, orang lain, maupun makhluk hidup lain dan tidak untuk diperdagangkan.

4. Makanan atau Pangan adalah segala sesuatu yang berasal dari sumber hayati produk pertanian, perkebunan, kehutanan, perikanan, peternakan, perairan, dan air, baik yang diolah maupun tidak diolah yang diperuntukkan sebagai makanan atau minuman bagi konsumsi manusia, termasuk bahan tambahan Pangan, bahan baku Pangan, dan bahan lainnya yang digunakan dalam proses penyiapan, pengolahan, dan/atau pembuatan makanan atau minuman.

5. Sertifikat Halal adalah suatu fatwa tertulis dari Majelis Ulamalndonesia

6 Philipus M. Hadjon, Perlindungan Bagi Rakyat di Indonesia, Bina IImu, Surabaya,1987, h. 1 
Media Komunikasi dan Informasi Hukum dan Masyarakat

(MUI) yang menyatakan kehalalan suatu produk sesuai dengansyari'at Islam. ${ }^{7}$

Lembaga Pengkajian Pangan Obat-Obatan dan Kosmetika Majelis Ulama Indonesia (LPPOM MUI) adalah sebuah lembaga yang dibentuk oleh MUI dengan tugas menjalankan fungsi MUI untuk melindungi konsumen muslim dalam mengonsumsi makanan, minuman, obat-obatan maupun kosmetika. ${ }^{8}$

\section{TINJAUAN PUSTAKA}

A. Tinjauan Umum Tentang Perlindungan Hukum Konsumen

1. Pengertian Perlindungan Hukum Konsumen

Perlindungan berasal dari kata lindung yang memiliki arti mengayomi, mencegah, mempertahankan dan membentengi. ${ }^{9}$ Perlindungan hukum adalah upaya pemerintah untuk menjamin adanya kepastian hukum untuk memberi perlindungan kepada masyarakat agar hak-haknya sebagai warga negara tidak dilanggar.

Menurut Satjipto Raharjo Perlindungan Hukum adalah memberikan pengayoman kepada hak asasi manusia yang dirugikan orang lain dan perlindungan tersebut diberikan kepada masyarakat agar mereka dapat menikmati semua hak-hak yang diberikan oleh hukum. ${ }^{10}$

Menurut Philipus M. Hadjon berpendapat bahwa perlindungan hukum adalah perlindungan akan harkat dan martabat, serta pengakuan terhadap hak-hak asasi manusia

7 Panji Adam, Kedudukan Sertifikasi Halal Dalam Sistem Hukum Nasional Sebagai Upaya Perlindungan Konsumen Dalam Hukum Islam,Amwaluna, Vol. 1 No. 1 , Januari, 2017, h.150

${ }^{8} \mathrm{http}: / /$ www.halalmui.org/images/stories/pdf/ sih-indonesia.pdf, diakses pada tanggal 8 Juli 2019, Pukul 8.19 WIB.

9 Dedy Sugiono, Kamus Besar Bahasa Indonesia, Pusat Bahasa, Jakarta, h.1085.

${ }^{10}$ Sajipto Rahardjo, IImu Hukum, Citra Adya Bakti, Bandung, 2014, h. 53. yang dimiliki oleh subyek hukum berdasarkan ketentuan hukum dari kesewenangan. ${ }^{11}$

Philipus M. Hadjon berpendapat bahwa prinsip perlindungan hukum bagi rakyat terhadap tindak pemerintah bertumpu dan bersumber dari konsep tentang pengakuan dan perlindungan terhadap hak-hak asasi manusia karena menurut sejarahnya di Barat, lahirnya konsep-konsep tentang pengakuan dan perlindugan terhadap hakhak asasi manusia diarahkan kepada pembatasan-pembatasan dan peletakan kewajiban pada masyarakat dan pemerintah. $^{12}$

Menurut CST Kansil Perlindungan Hukum adalah berbagai upaya hukum yang harus diberikan oleh aparat penegak hukum untuk memberikan rasa aman, baik secara pikiran maupun fisik dari gangguan dan berbagai ancaman dari pihak manapun.

Menurut Business English Dictionary, perlindungan konsumen adalah protecting consumers against unfair or illegal traders. Adapun Black's Law Dictionary mendefinisikan a statute that safeguards consumers in the use goods and services. Perlindungan konsumen adalah istilah yang dipakai untuk menggambarkan perlindungan hukum yang diberikan kepada konsumen dalam usahanya untuk memenuhi kebutuhannya dari hal-hal yang merugikan konsumen itu sendiri. ${ }^{13}$

Pengertian perlindungan konsumen di kemukakan oleh berbagai sarjana hukum salah satunya $A z$. Nasution mendefinisikan perlindungan konsumen adalah bagian dari hukum yang memuat asas-asasatau kaidahkaidah yang bersifat mengatur hubungan dan juga mengandung sifat yang melindungi kepentingan konsumen. ${ }^{14}$

\section{UU Perlindungan Konsumen Pasal 1}

ayat 1 tentang Perlindungan Konsumen

\section{${ }^{11}$ Philipus M. Hadjon, Loc.Cit \\ ${ }^{12}$ /bid, h.38}

13 Zulham, Hukum Perlindungan Konsumen, Prenadamedia Group, Jakarta, 2013, h.21.

14 Az. Nasution, Hukum Perlindungan Konsumen Suatu Pengantar, Diadit Media, Jakarta, 2002 h. 22. 
Media Komunikasi dan Informasi Hukum dan Masyarakat

menyatakan bahwa, perlindungan konsumen adalah segala upaya yang menjamin adanya kepastian hukum untuk memberi perlindungan kepada konsumen.

Perlindungan konsumen mempunyai cakupan yang luas, meliputi perlindungan konsumen terhadap barang dan jasa, yang berawal dari tahap kegiatan untuk mendapatkan barang dan jasa hingga sampai akibat-akibat dari pemakaian barang dan/atau jasa tersebut. Cakupan perlindungan konsumen dapat dibedakan dalam dua aspek, yaitu:

a. Perlindungan terhadap kemungkinan barang yang diserahkan kepada konsumen tidak sesuai dengan apa yang telah disepakati.

b. Perlindungan terhadap diberlakukannya syarat-syarat yang tidak adil kepada konsumen. ${ }^{15}$

Berdasarkan dari beberapa pengertian konsumen yang telah dikemukakan di atas, maka konsumen dapat dibedakan kepada tiga batasan, yaitu:

a. Konsumen komersial (commercial consumer), adalah setiap orang yang mendapatkan barang dan/atau jasa yang digunakan untuk memproduksi barang dan/atau jasa lain dengan tujuan mendapatkan keuntungan.

b. Konsumen antara (intermediate consumer), adalah setiap orang yang mendapatkan barang dan/atau jasa yang digunakan untuk diperdagangkan kembali juga dengan tujuan mencari keuntungan.

c. Konsumen akhir (ultimate consumer/end user), adalah setiap orang yang mendapatkan dan menggunakan barang dan/atau jasa untuk tujuan memenuhi kebutuhan kehidupan pribadi, keluarga, orang lain, dan makhluk hidup lainnya dan tidak untuk diperdagangkan kembali dan/atau untuk mencari keuntungan kembali. 16

15 Aulia Muthiah, Hukum Perlindungan Konsumen, Pustaka Baru, Yogyakarta, 2018, h.39.

16Zulham, Op. Cit,h.17-18
Hak konsumen sebagaimana tertuang dalam Pasal 4 UU Perlindungan Konsumen sebagai berikut:

a. Hak atas kenyamanan, keamanan, dan keselamatan dalam mengkonsumsi barang dan/atau jasa;

b. Hak untuk memilih barang dan/atau jasa serta mendapatkan barang dan/atau jasa tersebut sesuai dengan nilai tukar dan kondisi serta jaminan yang dijanjikan;

c. Hak atas informasi yang benar, jelas, dan jujur mengenai kondisi dan jaminan barang dan/atau jasa;

d. Hak untuk didengar pendapat dan keluhannya atas barang dan/atau jasa yang digunakan;

e. Hak untuk mendapatkan advokasi, perlindungan, dan upaya penyelesaian sengketa perlindungan konsumen secara patut;

f. Hak untuk mendapat pembinaan dan pendidikan konsumen;

g. Hak untuk diperlakukan atau dilayani secara benar dan jujur serta tidak diskriminatif;

h. Hak untuk mendapatkan kompensasi, ganti rugi dan/atau penggantian, apabila barang dan/atau jasa yang diterima tidak sesuai dengan perjanjian atau tidak sebagaimana mestinya;

i. Hak-hak yang diatur dalam ketentuan peraturan perundang-undangan lainnya.

Selain memiliki hak-hak, berdasarkan

Pasal 5 UU Perlindungan Konsumen, konsumen juga memiliki kewajiban yaitu:

a. Membaca atau mengikuti petunjuk informasi dan prosedur pemakaian atau pemanfaatan barang dan/atau jasa, demi keamanan dan keselamatan;

b. Beritikad baik dalam melakukan transaksi pembelian barang dan/atau jasa;

c. Membayar sesuai dengan nilai tukar yang disepakati;

d. Mengikuti upaya penyelesaian hukum sengketa perlindungan konsumen secara patut.

2. Pengertian Pelaku Usaha, Hak dan Kewajibannya

Pasal 1 angka 3 UU Perlindungan Konsumen disebutkan bahwapelaku usaha adalah setiap orang perseorangan atau badan usaha, baik yang berbentuk badan hukum 
Media Komunikasi dan Informasi Hukum dan Masyarakat

maupun bukan badan hukum yang didirikan dan berkedudukan atau melakukan kegiatan dalam wilayah hukum negara Republik Indonesia, baik sendiri maupun bersama-sama melalui perjanjian menyelenggarakan kegiatan usaha dalam berbagai bidang ekonomi.

Dalam penjelasan undang-undang yang termasuk dalam pelaku usaha adalah perusahaan, korporasi, BUMN, koperasi, importir, pedagang, distributor dan lain-lain.

Pasal 6 UU Perlindungan Konsumen, Produsen disebut sebagai pelaku usaha mempunyai hak sebagai berikut:

a. Hak untuk menerima pembayaran yang sesuai dengan kesepakatan mengenai kondisi dan nilai tukar barang dan/atau jasa yang diperdagangkan;

b. Hak untuk mendapat perlindungan hukum dari tindakan konsumen yang beritikad tidak baik;

c. Hak untuk melakukan pembelaan diri sepatutnya di dalam penyelesaian hukum sengketa konsumen;

d. Hak untuk rehabilitasi nama baik apabila terbukti secara hukum bahwa kerugian konsumen tidak diakibatkan oleh barang dan/atau jasa yang diperdagangkan;

e. Hak-hak yang diatur dalam ketentuan peraturan perundang-undangan lainnya.

Adapun dalam Pasal 7 UU Perlindungan

Konsumen diatur kewajiban pelaku usaha, sebagai berikut:

a. Beritikad baik dalam melakukan kegiatan usahanya;

b. Memberikan informasi yang benar, jelas dan jujur mengenai kondisi dan jaminan barang dan/atau jasa serta memberi penjelasan penggunaan, perbaikan dan pemeliharaan;

c. Memperlakukan atau melayani konsumen secara benar dan jujur serta tidak diskriminatif;

d. Menjamin mutu barang dan/atau jasa yang diproduksi dan/atau diperdagangkan berdasarkan ketentuan standar mutu barang dan/atau jasa yang berlaku;

e. Memberi kesempatan kepada konsumen untuk menguji, dan/atau mencoba barang dan/atau jasa tertentu serta memberi jaminan dan/atau garansi atas barang yang dibuat dan/atau yang diperdagangkan;

f. Memberi kompensasi, ganti rugi dan/atau penggantian atas kerugian akibat penggunaan, pemakaian dan pemanfaatan barang dan/atau jasa yang diperdagangkan;

g. Memberi kompensasi, ganti rugi dan/atau penggantian apabila barang dan/atau jasa yang dterima atau dimanfaatkan tidak sesuai dengan perjanjian.

Lebih lanjut, Pasal 8 UU Perlindungan

Konsumen menetapkan larangan-larangan bagi

pelaku usaha yang berujung pada kerugian

konsumen yaitu:

1) Pelaku usaha dilarang memproduksi dan/atau memperdagangkan barang dan/atau jasa yang :

a. tidak memenuhi atau tidak sesuai dengan standar yang dipersyaratkan dan ketentuan peraturan perundangundangan;

b. tidak sesuai dengan berat bersih, isi bersih atau netto, dan jumlah dalam hitungan sebagaimana yang dinyatakan dalam label atau etiket barang tersebut;

c. tidak sesuai dengan ukuran, takaran, timbangan dan jumlah dalam hitungan menurut ukuran yang sebenarnya;

d. tidak sesuai dengan kondisi, jaminan, keistimewaan atau kemanjuran sebagaimana dinyatakan dalam label, etiket atau keterangan barang dan/atau jasa tersebut;

e. tidak sesuai dengan mutu, tingkatan, komposisi, proses pengolahan, gaya, mode, atau penggunaan tertentu sebagaimana dinyatakan dalam label atau keterangan barang dan/atau jasa tersebut;

f. tidak sesuai dengan janji yang dinyatakan dalam label, etiket, keterangan, iklan atau promosi penjualan barang dan/atau jasa tersebut;

g. tidak mencantumkan tanggal kadaluwarsa atau jangka waktu penggunaan/pemanfaatan yang paling baik atas barang tertentu; 
Media Komunikasi dan Informasi Hukum dan Masyarakat

h. tidak mengikuti ketentuan berproduksi secara halal, sebagaimana pernyataan "halal" yang dicantumkan dalam label;

i. tidak memasang label atau membuat penjelasan barang yang memuat nama barang, ukuran, berat/isi bersih atau netto, komposisi, aturan pakai, tanggal pembuatan, akibat sampingan, nama dan alamat pelaku usaha serta keterangan lain untuk penggunaan yang menurut ketentuan harus di pasang/dibuat;

j. tidak mencantumkan informasi dan/atau petunjuk penggunaan barang dalam bahasa Indonesia sesuai dengan ketentuan perundangundangan yang berlaku.

2) Pelaku usaha dilarang memperdagangkan barang yang rusak, cacat atau bekas, dan tercemar tanpa memberikan informasi secara lengkap dan benar atas barang dimaksud.

3) Pelaku usaha dilarang memperdagangkan sediaan farmasi dan pangan yang rusak, cacat atau bekas dan tercemar, dengan atau tanpa memberikan informasi secara lengkap dan benar.

4) Pelaku usaha yang melakukan pelanggaran pada ayat (1) dan ayat (2) dilarang memperdagangkan barang dan/atau jasa tersebut serta wajib menariknya dari peredaran.

\section{Pasal 9 ayat (1) UU Perlindungan}

Konsumen menyatakan bahwa pelaku usaha dilarang untuk memperdagangkan, menawarkan, mempromosikan, mengiklankan suatu barang dan/atau jasa secara tidak benar, dan/atau seolah-olah:

a. Barang tersebut telah memenuhi dan/atau memiliki potongan harga, harga khusus, standar mutu tertentu, gaya atau mode tertentu, karakteristik tertentu, sejarah atau guna tertentu;

b. Barang tersebut dalam keadaan baik dan/atau baru;

c. Barang dan/atau jasa tersebut telah mendapatkan dan/atau memiliki sponsor, persetujuan, perlengkapan tertentu, keuntungan tertentu, ciri-ciri kerja atau aksesori tertentu;

d. Barang dan/atau jasa tersebut dibuat oleh perusahaan yang mempunyai sponsor, persetujuan atau afiliasi; e. Barang dan/atau jasa tersebut tersedia;

f. Barang tersebut tidak mengandung cacat tersembunyi;

g. Barang tersebut merupakan kelengkapan dari barang tertentu;

h. Barang tersebut berasal dari daerah tertentu;

i. Secara langsung atau tidak langsung merendahkan barang dan/atau jasa lain;

j. Menggunakan kata-kata yang berlebihan, seperti aman, tidak berbahaya, tidak mengandung risiko atau efek sampingan tanpa keterangan yang lengkap;

k. Menawarkan sesuatu yang mengandung janji yang belum pasti.

\section{B. Tinjauan Umum Tentang Produk Makanan}

\section{Halal}

\section{Pengertian Produk Makanan}

Dalam pengertian luas, produk ialah segala barang dan jasa yang dihasilkan oleh suatu proses sehingga produk berkaitan erat dengan teknologi. ${ }^{17}$ Menurut Pasal 1 angka 4 Undang-Undang Perlindungan Konsumen bahwa:

Barang adalah setiap benda, baik berwujud maupun tidak berwujud, baik bergerak maupun tidak bergerak, dapat dihabiskan maupun tidak dihabiskan, yang dapat untuk diperdagangkan, dipakai, dipergunakan, atau dimanfaatkan oleh konsumen.

Makanan atau pangan adalah kebutuhan dasar manusia yang paling utama dan pemenuhannya merupakan bagian dari hak asasi setiap rakyat di Indonesia. Untuk memenuhi kebutuhan perlu diselenggarakan suatu sistem pangan yang memberikan perlindunga, baik bagi pihak yang memproduksi maupun mengonsumsi.

Menurut Undang-Undang Republik Indonesia Nomor 18 Tahun 2012 tentang Pangan dinyatakan bahwa :

17Janus Sidabalok, Hukum Perlindungan Konsumen Di Indonesia, Bandung:Citra Aditya Bakti, 2006, h.18. 
Media Komunikasi dan Informasi Hukum dan Masyarakat

Pangan adalah segala sesuatu yang berasal dari sumber hayati produk pertanian, perkebunan, kehutanan, perikanan, peternakan, perairan, dan air, baik yang diolah maupun tidak diolah yang diperuntukkan sebagai makanan atau minuman bagi konsumsi manusia, termasuk bahan tambahan Pangan, bahan baku Pangan, dan bahan lainnya yang digunakan dalam proses penyiapan, pengolahan, dan/atau pembuatan makanan atau minuman.

2. Pengaturan Makanan Halal dalam Hukum Islam

Sumber hukum perlindungan konsumen dalam Islam, praktis sama persis dengan sumber hukum islam yang diakui oleh mayoritas ulama (jumhur ulama), yaitu: Al-Qur'an, Sunnah, ljma', dan Qiyas. Al-Qur'an dan Sunnah dapat berdiri sendiri sebagai dalil hukum, sedangkan ljma' dan Qiyas tidak dapat berdiri sendiri sebagai dalil hukum, karena proses ljma' dan Qiyas harus berdasarkan kepada dalil penyandaran dari Al-Qur'an dan Sunnah.

\section{Tinjauan Umum tentang Sertifikasi dan Labelisasi Halal di LPPOM MUI Sumatera Utara di Medan}

1. Pengertian Sertifikasi dan Labelisasi Halal

Sertifikasi Halal adalah Fatwa Tertulis Majelis Ulama Indonesia (MUI) yang menyatakan kehalalan suatu produk sesuai syari'at Islam setelah melalui proses pemeriksaan. Sertifikasi dibutuhkan untuk mengetahui validitas produk yang diolah, dikemas, dan diproduksi. Oppenheim dan Weston menjelaskan bahwa sertifikasi adalah tanda (mark) yang digunakan pada produk (barang dan/atau jasa) untuk menyatakan tentang bahan, cara pembuatan, kualitas, ketepatan (akurasi), karakteristik, pengelolaan, pengolahan, dan tenaga kerja dalam menghasilkan produk tersebut. ${ }^{18}$

Label Halal adalah tanda "HALAL" yang dicantumkan pada kemasan produk. Labelisasi adalah proses penyertaan label (pelabelan) yang dirancang untuk melindungi konsumen melalui informasi yang akurat mengenai jumlah, kualitas, dan isi produk. Labelisasi dibutuhkan agar konsumen dapat membandingkan produk lainnya yang bersaing. Dengan demikian, label harus mendeskripsikan dengan jelas setiap bahan asal yang terkandung dalam produk, termasuk bahan yang tersembunyi, seperti pengolahan dan bahan-bahan pendukung lainnya. ${ }^{19}$

Tujuan labelisasi adalah untuk mencegah penipuan, serta untuk membantu konsumen memaksimalkan pilihan terhadap produk untuk kemanfaatan dan kesejahteraan. Agar konsumen bertindak sesuai dengan kepentingan terbaik mereka dan berdasarkan pilihan. Tujuan label adalah sebagai informasi untuk membantu konsumen mengidentifikasi produk makanan yang paling sesuai dengan pilihan. ${ }^{20}$

Sertifikasi dan labelisasi membantu konsumen untuk mengetahui sifat dan bahan produk, sehingga memungkinkan bagi konsumen untuk memilh berbagai produk yang saling bersaing (competing products). Informasi inilah yang dibutuhkan konsumen pada produk panganan halal, dengan informasi yang simetris konsumen dapat menentukan pilihannya untuk mengonsumsi produk pangan halal, karena informasi yang simetris merupakan kesejahteraan bagi konsumen, sehingga

\footnotetext{
${ }^{18}$ Zulham, Op., Cit, h.113-114.

${ }^{19} /$ bid, h.114-115.

${ }^{20} /$ bid, h.114.
} 
Media Komunikasi dan Informasi Hukum dan Masyarakat

dengan sertifikasi dan labelisasi tercipta keadilan pasar bagi konsumen. ${ }^{21}$

\section{Prosedur Sertifikasi/Labelisasi Halal}

Pasal 1 angka 3 UU Jaminan Produk Halal menyatakan bahwa Proses Produk Halal (PPH) merupakan rangkaian kegiatan untuk menjamin kehalalan produk mencakup penyediaan bahan, pengolahan,penyimpanan, pengemasan, pendistribusian, penjualan, dan penyajian Produk.

Pengaturan sertifikasi dan labelisasi produk halal dalam UU Jamianan Produk Halal diatur dalam Pasal 4 yaitu produk yang diperdagangkan wajib bersertifikat halal. Sebagaimana Pasal 4 menyebutkan, Produk yang masuk, beredar, dan diperdagangkan di wilayah Indonesia wajib bersertifikat halal.

Kewajiban bersertifikat halal terhadap produk tidak berlaku bagi semua produk, karena Pasal 26 UUJPH mengecualikan kewajiban bersertifikat halal kepada pelaku usaha yang memang memproduksi produk dari bahan yang diharamkan. Bagi pelaku usaha yang memproduksi produk dari bahan haram, wajib mencantumkan keterangan tidak halal pada produknya. Ketentuan Pasal 26 UUJPH tersebut, dipengaruhi oleh Putusan Mahkamah Konstitusi Republik Indonesia Nomor 2/PUUIX/2011, terkait dengan Pengujian Pasal 58 ayat (4) Undang-Undang Republik Indonesia Nomor 18 Tahun 2009 tentang Peternakan dan Kesehatan Hewan terhadap Undang-Undang Dasar Negara Republik Indonesia Tahun 1945.

Pengaturan sertifikasi dan labelisasi produk halal dalam UUJPH, tidak melarang produksi dan perdagangan produk haram. Sepanjang produsen produk haram tersebut, mencantumkan keterangan tidak halal.

\footnotetext{
${ }^{21}$ Ibid, h. 116
}

Pandangan ini dipertegas dengan pengertian sertifikat halal adalah pengakuan kehalalan suatu produk yang dikeluarkan oleh Badan Penyelenggara Jaminan Produk Halal (BPJPH) berdasarkan fatwa halal tertulis yang dikeluarkan oleh Majelis Ulama Indonesia (MUI). Juga diperkuat dengan pengertian label halal adalah tanda kehalalan suatu produk.

Ketentuan Pasal 67 UUJPH ayat (1) menyebutkan, "Kewajiban bersertifikat halal bagi produk yang beredar dan diperdagangkan diwilayah Indonesia sebagaimana dimaksud dalam Pasal 4 mulai berlaku 5 tahun terhitung sejak undang-undang ini diundangkan." Ini berarti, mandatory halal certification bagi produk yang beredar dan diperdagangkan di Indonesia, mulai diberlakukan lima tahun ke depan sejak UUJPH diundangkan. Rumusan Pasal 67 ayat (2) dan (3) UUJPH, merupakan key rules untuk pengaturan jenis dan karakteristik produk yang wajib disertifikasi. Pasal 67 ayat (2) menyebutkan, "Sebelum kewajiban bersertifikat halal sebagaimana dimaksud pada ayat (1) berlaku, jenis produk yang bersertifikat halal diatur secara bertahap." Selanjutnya pada Pasal 67 ayat (3) menyebutkan, "Ketentuan mengenai jenis produk yang bersertifikat halal secara bertahap sebagaimana diatur pada ayat (2) diatur dalam peraturan pemerintah."

Penyelenggaraan Jaminan Produk Halal (JPH) merupakan tanggung jawab negara, bahwa Pemerintah bertanggung jawab dalam menyelenggarakan JPH. Ketentuan

\section{A. Teknik Pengumpulan Data \\ 1. Sumber Data}

\section{a. Data Primer}

Data primer diperoleh dari hasil penelitian pada Lembaga Pengkajian Pangan, Obatobatan, dan Kosmetika Majelis Ulama 
Media Komunikasi dan Informasi Hukum dan Masyarakat

Indonesia(LPPOM MUI Sumatera Utara di Medan)

\section{b. Data sekunder}

Data sekunder diperoleh dari penelitian kepustakaan berupa bahan-bahan hukum yang terdiri dari

1) Bahan Hukum Primer

Bahan hukum primer adalah bahan hukum berupa peraturan perundan-undangan yang berkaitan dengan perlindungan konsumen.

2) Bahan Hukum Sekunder

Bahan hukum sekunder yaitu bahanbahan yang erat hubungannya dengan bahan hukum primer, yakni buku-buku, jurnal-jurnal hukum, dan majalah yang berhubungan dengan objek yang diteliti.

\section{Alat Pengumpulan Data}

a. Penelitian Kepustakaan, Data diperoleh dari beberapa literatur berupa bukubuku ilmiah, peraturan perundangundangan, jurnal-jurnal, serta sumber kepustakaan lainnya .

b. Penelitian Lapangan, yaitu dengan melakukan wawancara di Lembaga Pengkajian Pangan, Obat-obatan, dan Kosmetika Ulama Indonesia(LPPOM MUI Sumatera Utara di Medan)

\section{E. Analisis Data}

Analisis data yang digunakan adalah analisis data kualitatif yaitu yang dilakukan dengan merangkai data yang dikumpulkan secara sistematis dan mendapatkan suatu keadaan yang diteliti, Bahan hukum penelitian diklasifikasikan sesuai dengan permasalahan penelitian, hasil klasifikasi bahan hukum tersebut selanjutnya disistematisasikan, Bahan hukum yang telah disistematisasikan kemudian dianalisis untuk dijadikan dasar dalam mengambil kesimpulan. ${ }^{22}$

\section{HASIL PENELITIAN DAN PEMBAHASAN}

\section{A. Perlindungan Hukum Bagi Konsumen Muslim Terhadap Peredaran Makanan Yang Tidak Bersertifikat Halal}

Pemerintah bertanggung jawab dalam menyelenggarakan Jaminan Produk Halal (JPH) yang pelaksanaannya dilakukan oleh Badan Penyelenggara Jaminan Produk Halal (BPJPH). Dalam menjalankan wewenangnya, BPJPH bekerja sama dengan kementerian dan/atau lembaga terkait, MUI, dan LPH. Jaminan penyelenggaraan produk halal bertujuan untuk memberikan kenyamanan, keamanan, keselamatan dan kepastian ketersediaan produk halal bagi masyarakat dalam mengonsumsi dan menggunakan produk makanan. Hal ini menjadi penting sebagai bagian dari upaya melindungi konsumen dari produk-produk makanan yang tidak halal.Pada dasarnya keberadaan jaminan produk pangan halal berangkat dari informasi yang benar, jelas, dan lengkap baik secara kuantitatif maupun kualitas dari produk pangan yang mereka konsumsi. ${ }^{23}$

Pencantuman label halal sebagai konsekuensi sebuah produk yang bersertifikat halal akan mengembalikan hak-hak konsumen untuk menyeleksi dan mengkonsumsi jenis makanan yang mereka hendak konsumsi. Oleh karena itu pencantuman label harus terbuka dan jelas terlihat, sehingga menunjukan adanya



${ }^{23} \mathrm{KN}$ Sopyan Hasan, Sertifikasi Halal dalam Hukum Positif: Regulasi dan Implementasi di Indonesia, Aswaja Presindo. Cetakan I, Agustus 2014, hlm. 239 
Media Komunikasi dan Informasi Hukum dan Masyarakat

itikad baik dari pelaku usaha untuk mengembalikan hak-hak konsumen. Karena selain untuk menjamin aspek kesehatan, juga bahkan yang sangat penting adalah sebagai bentuk pemberian jaminan perlindungan dan kepuasan batiniah masyarakat. ${ }^{24}$

Pengaturan perlindungan hukum bagi konsumen muslim terhadap peredaran makanan tidak bersertifikat halal di atur dalam UndangUndang Republik Indonesia Nomor 18 Tahun 2012 tentang Pangan dan Undang-Undang Republik Indonesia Nomor 8 Tahun 1999 tentang Perlindungan Konsumen, UndangUndang Republik Indonesia Nomor 33 Tahun 2014 tentang Jaminan Produk Halal.

1. Undang-Undang Republik Indonesia Nomor 18 Tahun 2012 tentang Pangan

Undang-Undang Republik Indonesia Nomor 18 Tahun 2012 tentang Pangan terdapat beberapa pasal yang terkait dengan kehalalan produk pangan yaitu pasal 97 ayat (1), (2) dan (3) dan Pasal 102 ayat (1), (2), dan (3). Adapun bunyi pasal-pasaltersebut adalah sebagai berikut :

Pasal 97 :

(1)Setiap orang yang memproduksi Pangan di dalam negeri untuk diperdagangkan wajib mencantumkan label di dalam dan/atau pada Kemasan Pangan.

(2)Setiap orang yang mengimpor pangan untuk diperdagangkan wajib mencantumkan label di dalam dan/ atau pada kemasan pangan pada saat memasuki wilayah Negara Kesatuan Republik Indonesia.

(3)Pencantuman label di dalam dan/atau pada kemasan Pangan sebagaimana dimaksud pada ayat (1) dan ayat (2) ditulis atau dicetak dengan menggunakan bahasa Indonesia serta memuat paling sedikit keterangan mengenai : a. Nama produk;

b. Daftar bahan yang digunakan;

c. Berat bersih dan isi bersih;

d. Nama dan alamat pihak yang memproduksi atau mengimpor;

e. Halal bagi yang dipersyaratkan;

f. Tanggal dan kode produksi;

g. Tanggal,bulan dan tahun kadaluarsa;

h. Nomor izin edar bagi Pangan Olahan; dan

i. Asal usul bahan Pangan tertentu.

Pasal 102 :

(1) Setiap Orang yang melanggar ketentuan sebagaimana dimaksud dalam Pasal 97 ayat (1), Pasal 99, dan Pasal 100 ayat (2) dikenai sanksi administratif.

(2) Setiap Orang yang melanggar ketentuan sebagaimana dimaksud dalam Pasal 97 ayat (2) wajib mengeluarkan dari dalam wilayah Negara Kesatuan Republik Indonesia atau memusnahkan Pangan yang diimpor.

(3) Sanksi administratif sebagaimana dimaksud pada ayat (1) berupa:

a. Denda;

b. Penghentian sementara dari kegiatan, produksi, dan/atau peredaran;

c. Penarikan Pangan dari peredaran oleh produsen;

d. Ganti rugi; dan/atau

e. Pencabutan izin.

2. Undang-Undang Republik Indonesia Nomor 8 Tahun 1999 tentang Perlindungan Konsumen

Undang-Undang Republik Indonesia Nomor 8 Tahun 1999 tentang Perlindungan Konsumen berpengaruh dan memberi perlindungan terhadap konsumen muslim dalam mengkonsumsi makanan halal. Berdasarkan Pasal 1 ayat (1) menyatakan bahwa perlindungan konsumen adalah segala upaya yang menjamin adanya kepastian hukum untuk memberi perlindungan kepada konsumen. Dan

${ }^{24}$ Ibid, hlm. 240 
Media Komunikasi dan Informasi Hukum dan Masyarakat

pada Pasal 2 termuat asas dari perlindungan konsumen yang berbunyi: Perlindungan konsumen berasaskan manfaat, keadilan, keseimbangan, keamanan, dan keselamatan konsumen, serta kepastian hukum.

Pasal 4 mengatur hak-hak konsumen, Pasal 5 mengatur tentang kewajiban konsumen dan Pasal 7 mengatur tentang kewajiban pelaku usaha. Berdasarkan tiga Pasal tersebut, konsumen berhak mendapatkan informasi yang jelas, benar dan jujur mengenai kondisi dan jaminan barang dan/atau jasa. Jadi berdasarkan uraian tersebut, pelaku usaha wajib memberikan informasi yang benar terhadap produk agar menjamin kepuasan konsumen dan tidak merugikan konsumen jika ada beberapa bahanbahan berbahaya atau di haramkan. Dengan ketentuan ini, konsumen mendapatkan perlindungan hukum atas produk pangan yang beredar di Indonesia.

Undang-Undang Nomor 8 Tahun 1999 tentang Perlindungan Konsumen telah memberikan perlindungan hukum terhadap jaminan produk halal pada makanan tercantum pada Pasal 8 yang berisi tentang pengaturan tentang perbuatan yang dilarang bagi pelaku usaha sebagaimana yang telah penulis jelaskan pada tinjauan pustaka.

Pada Pasal 8 Ayat (1) huruf $\mathrm{h}$ dinyatakan bahwa bagi pelaku usaha yang tidak mengikuti ketentuan berproduksi secara halal, sebagaimana pernyataan "halal" yang dicantumkan dalam label. Dari Pasal 8 Ayat (1) huruf $\mathrm{h}$ ini menyatakan bahwa apabila pelaku usaha yang telah mencantumkan label halal pada label produknya haruslah melakukan ketentuan produksi secara halal dan sesuai dengan syariat Islam. Akan tetapi apabila pada kenyataannya produksi yang dilakukan ternyata tidak dilakukan dengan halal maka akan diberikan sanksi pidana yang ada pada Pasal 62 Undang-Undang Nomor 8 tentang Perlindungan Konsumen.

Dalam Pasal 62 Undang-Undang Republik Indonesia Nomor 8 Tahun 1999 tentang Perlindungan Konsumen, tindakan merugikan konsumen dan atau mengganggu kehidupan perekonomian nasional dikelompokkan ke dalam tiga kelompok, yaitu:

1) Tindakan pelaku usaha yang melanggar ketentuan sebagaimana dimaksud dalam Pasal 8, Pasal 9. Pasal 10, Pasal 13 ayat (2), Pasal 15, Pasal 17 ayat (1) huruf $a$, huruf $b$, huruf $c$, ayat (2) dan Pasal 18 dipidana dengan pidana penjara paling lama 5 (lima) tahun atau pidana denda paling banyak $\mathrm{Rp}$. 2.000.000.000,00. (dua miliar rupiah).

2) Tindakan pelaku usaha yang melanggar ketentuan sebagaimana dimaksud dalam Pasal 11, Pasal 12, Pasal 13 ayat (1), Pasal 14, Pasal 16, dan Pasal 17 ayat (1) huruf $d$ dan huruf $f$ dipidana penjara paling lama 2 (dua) tahun atau pidana denda paling banyak Rp. $500.000 .000,00$. (lima ratus juta rupiah).

3) Tindakan pelaku usaha yang mengakibatkan luka berat, sakit berat, cacat tetap, atau kematian, diberlakukan ketentuan yang berlaku.

Penulis berpendapat dengan adanya sanksi pidana yang diterapkan dalam UndangUndang Perlindungan Konsumen dapat memberikan perlindungan kepada konsumen khususnya konsumen muslim. Karena dengan adanya label halal dalam produk makanan, konsumen muslim menjadi percaya dan yakin untuk menggunakan produk ataupun makanan tersebut. Sehingga apabila produsen ataupun pelaku usaha yang pada kenyataannya dalam kegiatan produksinya tidak dilakukan dengan cara yang halal dapat diberikan sanksi yang sesuai dengan peraturan perundang-undangan.

Uraian diatas apabila dihubungkan dengan hak-hak konsumen, dapat dikatakan bahwa ketentuan sebagaimana diatur di dalam 
Media Komunikasi dan Informasi Hukum dan Masyarakat

pasal-pasal di atas bertujuan untuk melindungi konsumen atas hak-haknyatermasuk didalamnya hak atas kenyamanan, keamanan dan keselamatan dalam mengkonsumsi produk makanan.

3. Undang-Undang Republik Indonesia Nomor 33 Tahun 2014 tentang Jaminan Produk Halal

Konsiderans Undang-Undang Nomor 33 Tahun 2014 tentang Jaminan Produk Halal menyatakan pada Konsiderans b dinyatakan bahwa untuk menjamin setiap pemeluk agama untuk beribadah dan menjalankan ajaran agamanya, negara berkewajiban memberikan perlindungan dan jaminan tentang kehalalan produk yang dikonsumsi oleh masyarakat. Sehingga dengan lahirnya Undang-Undang ini negara telah hadir untuk memberikan perlindungan untuk menjamin kehalalan produk yang dikonsumsi oleh masyarakat.

Undang-Undang Republik Indonesia Nomor 33 Tahun 2014 tentang Jaminan Produk Halal telah mengatur secara tegas tentang kewajiban sertifikasi halal, yaitu pada Pasal 4 menyatakan secara jelas bahwa "Produk yang masuk, beredar dan diperdagangkan di wilayah Indonesia wajib bersertifikat Halal". " Kewajiban bersertifikat halal bagi produk yang beredar dan diperdagangkan di wilayah Indonesia sebagaimana dimaksud di atas mulai berlaku 5 (lima) Tahun terhitung sejak Undang-Undang ini diundangkan. Produk yang masuk, beredar dan diperdagangkan di wilayah Indonesia wajib bersertifikat halal artinya bahwa sertifikat halal bersifat wajib bagi importir maupun pelaku usaha yang ada di dalam negeri. Jadi hanya 2 (dua) jenis produk yang beredar di Indonesia, yakni produk Halal dan Produk Non Halal.
Tidak harus disyaratkan muslim yang memproduksi makanan lalu diberi sertifikat halal apabila perusahaannya kecil dan petugasnya 1 atau 2 orang saja dibagian produksinya harus muslim. Akan tetapi jika perusahaan besar seperti pabrik, maka pihak yang ditempatkan dibagian produkis bisa muslim maupun non muslim, yang terpenting menjaga agar tidak terjadi kontaminasi dengan najis dan bahan haram. ${ }^{25}$

$$
\text { Pelaku Usaha yang memproduksi }
$$

Produk dari Bahan yang diharamkan dikecualikan dalam mengajukan permohonan Sertifikasi Halal. Mengenai Produk non halal diatur dalam Pasal 18 dan Pasal 20.Produk dari bahan yang diharamkan dikecualikan dari mengajukan permohonan Sertifikat Halal tercantum dalam Pasal 26 UUJPH dan Peraturan Pemerintah Nomor 31 Tahun 2019 pada Pasal 2 yang menjelaskan bahwa Produk yang berasal dari bahan yang diharamkan wajib diberikan keterangan tidak halal. Sehingga pelaku usaha wajib mencantumkan keterangan tidak halal pada produk yang diproduksi dan diedarkan.Apabila pelaku usaha tidak memenuhi kewajiban mencantumkan keterangan tidak halal pada produknya akan dikenai sanksi administratif berupa :
a. Teguran lisan
b. Peringatan tertulis
c. Denda administratif
Penjelasan Pasal 2 Undang-Undang Republik Indonesia Nomor 33 Tahun 2014 Tentang Jaminan Produk Halal juga diatur tentang asas-asas penyelenggaraan jaminan produk halal (JPH), yaitu;

${ }^{25}$ Wawancara dengan Retni Kustiyah Mardiati, selaku Sekretaris LPPOM MUI Sumatera Utara di Medan, pada tanggal 2 November 2019 pukul 10.00 WIB. 
Media Komunikasi dan Informasi Hukum dan Masyarakat

a. Asas perlindungan adalah bahwa dalam menyelenggarakan JPH bertujuan melindungi masyarakat muslim.

b. Asas keadilan, bahwa dalam penyelenggaraan JPH harus mencerminkan keadilan secara proporsional bagi setiap warga negara.

C. Asas kepastian hukum, adalah bahwa penyelenggaraan JPH bertujuan memberikan kepastian hukum mengenai kehalalan suatu produk yang dibuktikan dengan sertifikasi halal.

d. Asas akuntabilitas dan transparansi adalah bahwa kegiatan penyelenggaraan $\mathrm{JPH}$ harus dapat dipertanggungjawabkan kepada masyarakat sebagai pemegang kedaulatan tertinggi negara sesuai dengan ketentuan peraturan perundangundangan.

e. Asas efektivitas dan efisiensi adalah bahwa penyelenggaraan JPH dilakukan dengan berorientasi pada tujuan yang tepat guna dan berdaya guna serta meminimalisasi penggunaan sumber daya yang dilakukan dengan cara cepat, sederhana, dan biaya ringan atau terjangkau.

f. Asas profesionalitas adalah bahwa penyelenggaraan JPH dilakukan dengan mengutamakan keahlian yang berdasarkan kompetensi dan kode etik.

Menurut penulis, dengan adanya UUJPH ini akan memberikan kepastian dan jaminan bagi konsumen muslim dalam mengkonsumsi produk makanan yang beredar dimasyarakat, baik produk dalam negeri maupun produk import. Sehingga pelaku usaha berusaha memberikan perlindungan kepada konsumen muslim secara tegas. Karena dengan hadirnya UUJPH mewajibkan pelaku usaha untuk mendaftarkan produk makanannya bersertifikat halal.

Sesuai dengan pernyataan Ibu Retni Kustiyah Mardiati, S.Si selaku Sekretaris LPPOM MUI Sumut di Medan, bahwasannya produk makanan yang beredar di wilayah Indonesia wajib bersertifikat halal baik produk dalam negeri maupun produk import, dan mendaftarkannya ke lembaga yang berwenang yaitu BPJPH setelah di berlakukannya UUJPH pada tanggal 17 Oktober 2019. ${ }^{26}$

Setelah dikaitkan dengan peraturan perundang-undangan lainya menurut penulis sanksi yang dapat diterapkan bagi pelaku usaha yang tidak membuat sertifikasi adalah pada Pasal Pasal 97 Undang-Undang Nomor 18 Tahun 2012 tentang Pangan yang pada ayat (1) menyatakan:

"Setiap orang yang memproduksi Pangan di dalam negeri untuk diperdagangkan wajib mencantumkan label di dalam dan/atau pada Kemasan Pangan." dinyatakan :

Kemudian pada ayat

Pencantuman label di dalam dan/atau pada kemasan Pangan sebagaimana dimaksud pada ayat (1) dan ayat (2) ditulis atau dicetak dengan menggunakan bahasa Indonesia serta memuat paling sedikit keterangan mengenai :

a. Nama produk;

b. Daftar bahan yang digunakan;

c. Berat bersih dan isi bersih;

d. Nama dan alamat pihak yang memproduksi atau mengimpor;

e. Halal bagi yang dipersyaratkan;

f. Tanggal dan kode produksi;

g. Tanggal,bulan dan tahun kadaluarsa;

h. Nomor izin edar bagi Pangan Olahan; dan

i. Asal usul bahan Pangan tertentu.

Pasal 97 ayat (3) huruf e telah jelas bahwa lebel dalam kemasan pangan harus memuat hal bagi yang dipersyaratkan. Mengenai sanksi yang diberikan apabila melanggar Pasal 97 ayat (1) ada pada Pasal 102 :

(1) Setiap Orang yang melanggar ketentuan sebagaimana dimaksud dalam Pasal 97 ayat (1), Pasal 99, dan Pasal 100 ayat (2) dikenai sanksi administratif.

${ }^{26}$ Wawancara dengan Retni Kustiyah Mardiati, selaku Sekretaris LPPOM MUI Sumatera Utara di Medan, pada tanggal 2 November 2019 pukul 10.00 WIB. 
Media Komunikasi dan Informasi Hukum dan Masyarakat

(2) Setiap Orang yang melanggar ketentuan sebagaimana dimaksud dalam Pasal 97 ayat (2) wajib mengeluarkan dari dalam wilayah Negara Kesatuan Republik Indonesia atau memusnahkan Pangan yang diimpor.

(3) Sanksi administratif sebagaimana dimaksud pada ayat (1) berupa:
a. Denda;
b. Penghentian sementara dari kegiatan, produksi, dan/atau peredaran;
c. Penarikan Pangan dari peredaran oleh produsen;
d. Ganti rugi; dan/atau
e. Pencabutan izin.

\section{B. Peran Lembaga Pengkajian Pangan}

Obat-Obatan Dan Kosmetika Majelis Ulama Indonesia (LPPOM MUI) Dalam Hal Pengawasan Dan Memberikan Kepastian Hukum Terhadap Masyarakat Di Kota Medan

Lahirnya Undang-Undang Jaminan Produk Halal (UU JPH) memperkuat adanya kepastian hukum dan pengawasan produk halal yang beredar di Indonesia. Pemerintah memiliki kewenangan memberikan pelayanan, perlindungan dan jaminan kepada seluruh masyarakat di Indonesia, khususnya adanya kepastian hukum dan jaminan halal bagi konsumen muslim.

Pemerintah melakukan pengawasan terhadap peredaran makanan halal di atur dalam Pasal 49, Pasal 50 dan Pasal 51 Undang-Undang Republik Indonesia Nomor 33 Tahun 2014 tentang Jaminan Produk Halal.

Pasal 49:

BPJPH melakukan pengawasan terhadap JPH.

Pasal 50:

Pengawasan JPH dilakukan terhadap:
a. LPH;
b. Masa berlaku Sertifikat Halal;
c. Kehalalan Produk;

d. Pencantuman keterangan tidak halal;

e. Pemisahan lokasi, tempat dan alat penyembelihan, pengolahan, penyimpanan, pengemasan, pendistribusian, penjualan, serta penyajian antara Produk Halal dan tidak halal;

f. Keberadaan Penyelia Halal; dan/atau

g. Kegiatan lain yang berkaitan dengan JPH.

Pasal 51:

1) BPJPH dan kementrian dan/atau lembaga terkait yang memiliki kewenangan pengawasan JPH dapat melakukan pengawasan secara sendiri-sendiri atau bersama-sama.

2) Pengawasan JPH dengan kementerian dan/atau lembaga terkait sebagaimana dimaksud pada ayat (1) dilaksanakan sesuai dengan ketentuan peraturan perundangan-undangan.

Pengawasan adalah segala usaha atau kegiatan untuk mengetahui dan menilai kenyataan yang sebenarnya mengenai pelaksanaan tugas atau kegiatan, apakah sesuai yang semestinya atau tidak. "yang semestinya" dalam pengertian ini adalah tolok ukur yang mengandung tiga segi yaitu: sesuai dengan rencana yang ditetapkan, sesuai dengan peraturan perundang- undangan dan ketentuan lainyang berlaku serta memenuhi prinsip- prinsip daya guna (efisiensi) dan hasil guna (efektifitas). ${ }^{27}$

Seperti yang telah dijelaskan pada pembahasan sebelumnya bahwa sejak berlakunya UU JPH, peran LPPOM MUI adalah sebagai Lembaga Pemeriksa Halal (LPH).

Pasal 13 UU JPH menyatakan untuk mendirikan LPH sebagaimana dimaksud dalam Pasal 12, harus dipenuhi persyaratan:

a. Memiliki kantor sendiri dan perlengkapannya;

${ }^{27}$ Jum Anggriani, Hukum Administrasi Negara, Graha Ilmu, Yogyakarta, 2012, h. 78 
Media Komunikasi dan Informasi Hukum dan Masyarakat

b. Memiliki akreditasi dari BPJPH;

c. Memiliki Auditor Halal paling sedikit 3 (tiga) orang; dan

d. Memiliki laboratorium atau kesepakatan kerja sama dengan lembaga lain yang memiliki laboratorium.

Pasal 15 UU JPH menyatakan Auditor Halal bertugas:

a. Memeriksa dan mengkaji Bahan yang digunakan;

b. Memeriksa dan mengkaji proses pengolahan Produk;

c. Memeriksa dan mengkaji sistem penyembelihan;

d. Meneliti lokasi Produk;

e. Meneliti peralatan, ruang produksi, dan penyimpanan;

f. Memeriksa pendistribusian dan penyajian Produk;

g. Memeriksa sistem jaminan halal Pelaku Usaha; dan

h. Melaporkan hasil pemeriksaan dan/atau pengujian kepada LPH.

Uraian diatas telah jelas menggambarkan peranan LPPOM MUI sebagai LPH dimana LPPOM akan menjadi lembaga yang melakukan proses pemeriksaan bahan makanan, memeriksa pengolahan produk, meneliti peralatan, ruang produksi, serta memeriksa sistem jaminan halal.

Selain itu peran dari LPPOM MUI sebagai LPH adalah menyerahkan hasil pemeriksaan dan/atau pengujian kehalalan produk kepada BPJH. Hal ini termuat dalam Pasal 23 Peraturan Pemerintah Nomor 31 Tahun 2019 yang isinya:

1. Kerja sama BPJPH dengan MUI mengenai penetapan kehalalan Produk sebagaimana dimaksud dalam Pasal 21 ayat (1) huruf b dilaksanakan dengan ketentuan :

a. LPH menyerahkan hasil pemeriksaan dan/atau pengujian kehalalan Produk kepada BPJPH yang meliputi dokumen :

1) Produk dan Bahan yang digunakan;

2) PPM;

3) Hasil analisis atau/spesifikasi;

4) Berita acara pemeriksaan; dan

5) Rekomendasi b. Terhadap hasil pemeriksaan dan/atau pengujian sebagaimana dimaksud pada huruf a, BPJPH melakukan verifikasi alas dokumen yang disampaikan LPH;

c. BPJPH menyampaikan hasil verifikasi sebagaimana dimaksud pada huruf $b$ kepada MUI;

d. MUI mengkaji hasil verifikasi BPJPH sebagaimana dimaksud pada huruf $\mathrm{C}$ melalui sidang fatwa halal dengan mengikutsertakan pakar, unsur kementrian terkait, lembaga terkait dan/atau institusi terkait;

e. Dalam hal sidang fatwa halal memerlukan informasi tambahan yang belum tercantum dalam dokumen yang diajukan oleh BPJPH, MUI mengembalikan dokumen tersebut untuk dilengkapi;

f. Hasil sidang fatwa halal berupa penetapan kehalalan atau ketidakhalalan produk yang ditandatangani oleh ketua dan sekertaris Komisi Fatwa MUI dan diketahui oleh Ketua Umum MUI: dan

g. Penetapan kehalalan atau ketidakhalalan produk disampaikan kepada BPJPH paling lama 30 (tiga puluh) hari kerja sejak MUI menerima hasil verifikasi dari BPJPH

2. Pelaksanaan sidang fatwa halal oleh MUI sebagaimana dimaksud pada ayat (1) huruf d difasilitasi oleh BPJPH.

3. Keputusan penetapan kehalalan produk sebagaimana dimaksud pada ayat (1) huruf $f$ disampaikan kepada BPJPH untuk menjadi dasar penerbitan Sertifikat Halal

Selanjutnya mengenai pengawasan, LPPOM MUI tidak ada melakukan pengawasan, karena yang seharusnya melakukan pengawasan adalah pemerintah seperti yang telah penulis utarakan pada awal pembahasan.Akan tetapi, LPPOM MUI menghimbau agar masyarakat membeli produk makanan yang berlabel halal. Hal ini tentunya agar masyarakat merasa terjamin dengan makanan yang dikonsumsinya tanpa ragu akan kehalalannya, karena makanan yang berlabel halal tentunya sudah melalui proses verifikasi 
Media Komunikasi dan Informasi Hukum dan Masyarakat

seperti yang penulis jelaskan pada skripsi ini. ${ }^{28}$ LPPOM MUI dalam melakukan promosi kepada pelaku usaha agar mendaftarkan produk makanannya bersertifikat halal dengan cara memberikan edukasi kepada masyarakat untuk mengonsumsi makanan yang halal. Sehingga masyarakat terdorong keinginannya untuk mengonsumsi makanan yang halal dan pelaku usaha/perusahaan mendaftarkan produk makanannya bersertifikat halal. ${ }^{29}$

\section{PENUTUP}

\section{A. Kesimpulan}

1. Pengaturan perlindungan hukum bagi konsumen muslim terhadap peredaran makanan tidak bersertifikat halal di atur dalam Undang-Undang Republik Indonesia Nomor 18 Tahun 2012 tentang Pangan dan Undang-Undang Republik Indonesia Nomor 8 Tahun 1999 tentang Perlindungan Konsumen, Undang-Undang Republik Indonesia Nomor 33 Tahun 2014 tentang Jaminan Produk Halal.

2. Peranan LPPOM MUI dalam sertifikasi halal adalah sebagai LPH dimana LPPOM akan menjadi lembaga yang melakukan proses pemeriksaan bahan makanan, memeriksa pengolahan produk, meneliti peralatan, ruang produksi, serta memeriksa sistem jaminan halal.Selain itu peran dari LPPOM MUI sebagai LPH adalah menyerahkan hasil pemeriksaan dan/atau pengujian kehalalan produk kepada BPJH.

${ }^{28}$ Wawancara dengan Retni Kustiyah Mardiati, selaku Sekretaris LPPOM MUI Sumatera Utara di Medan, pada tanggal 2 November 2019 pukul 10.00 WIB.

${ }^{29}$ Wawancara dengan Retni Kustiyah Mardiati, selaku Sekretaris LPPOM MUI Sumatera Utara di Medan, pada tanggal 2 November 2019 pukul 10.00 WIB.

\section{B. Saran}

1. Lahirnya Undang-Undang Jaminan Produk Halal telah mewajibkan setiap produk melakukan sertifikasi halal .akan tetapi kewajiban ini tidak disertakan sanksi. Tentunya ini akan menghambat pelaksanaan jaminan produk halal akibat tidak ada sanksi kepada pihak yang tidak melakukan sertifikasi halal. Penulis memberi saran agar diatur lebih jauh tentang sanksi apabila pelaku usaha tidak melakukan sertifikasi halal.

2. Pemerintah seharusnya memberi kewenangan yang lebih kepada LPPOM MUI dalam melakukan sertifikasi halal, supaya LPPOM MUI dapat melakukan pengawasan terhadap makanan tidak berlabel halal yang beredar dimasyarakat.

\section{DAFTAR BACAAN}

\section{A. Buku}

Ahmad Hatta, dkk. Bimbingan Islam untuk Hidup Muslim, Magfirah Pustaka, Jakarta Timur, 2016, h. 359.

Aisjah Girindra, Dari Sertifikasi Menuju Labelisasi Halal , Pustaka Jurnal Halal, Jakarta, 2008

Aisjah Girindra Pengukir Sejarah Sertifikasi Halal, Jakarta, LPPOM MUI,2005

Aulia Muthiah, Hukum Perlindungan Konsumen, Pustaka Baru, Yogyakarta, 2018

Az. Nasution, Hukum Perlindungan Konsumen Suatu Pengantar, Diadit Media, Jakarta, 2002

Bambang Sunggono, Metode Penelitian Hukum, PT. Raja Grafindo Perkasa. Jakarta, 2003

Celina Tri Siwi Kristiyanti, Hukum Perlindungan Konsumen, Sinar Grafika, Jakarta, 2018 
Media Komunikasi dan Informasi Hukum dan Masyarakat

Dedy Sugiono, Kamus Besar Bahasa Indonesia, Pusat Bahasa, Jakarta, h. 1085 .

Inosentius Samsul, Perlindungan Konsumen, Kemungkinan Penerapan Tanggung Jawab Mutlak, Universitas Indonesia, 2004

Janus Sidabalok, Hukum Perlindungan Konsumen Di Indonesia, Bandung:Citra Aditya Bakti, 2006

Jum Anggriani, Hukum Administrasi Negara, Graha llmu, Yogyakarta, 2012

KN Sopyan Hasan, Sertifikasi Halal dalam Hukum Positif: Regulasi dan Implementasi di Indonesia, Aswaja Presindo. Cetakan I, Agustus, 2014

Munir Fuady, Pengantar Hukum Bisnis, Citra Aditya Bakti, Bandung,2016

Philipus M. Hadjon, Perlindungan Bagi Rakyat di Indonesia, Bina IImu, Surabaya, 1987

Rosmawati, Pokok-Pokok Perlindungan

Hukum Prenadamedia Group Depok, 2016

Sajipto Rahardjo, IImu Hukum, Citra Adya Bakti, Bandung, 2014

Soerjono Soekanto, Pengantar Penelitian Hukum Universitas Indonesia, Jakarta, 1984

Zulham, Hukum Perlindungan Konsumen, Prenadamedia, Jakarta, 2016

\section{B. Peraturan Perundangan-Undangan}

Undang-Undang Republik Indonesia Nomor 5 Tahun 1999 tentang Larangan Praktek Monopoli dan Persaingan Usaha Tidak Sehat

Undang-Undang Republik Indonesia Nomor 8 Tahun 1999 tentang Perlindungan Konsumen

Undang-Undang Republik Indonesia Nomor 18 Tahun 2012 tentang Pangan

Undang-Undang Republik Indonesia Nomor 33 Tahun 2014 tentang Jaminan Produk Halal
Peraturan Pemerintah Republik Indonesia Nomor 31 Tahun 2019 tentang Peraturan Pelaksanaan UndangUndang Republik Indonesia Nomor 33 Tahun 2014 tentang Jaminan Produk Halal

\section{Jurnal}

Kurniawan, Budi Sutrisno dan Dwi Martini, Tanggung jawab Pelaku Usaha terhadap Pemberian Label Halal pada Produk Makanan dan Minuman Perspektif Hukum Perlindungan Konsumen, Jurnal Penelitian UNRAM, vol.18, No. 1, Februari, 2014. H. 16

Panji Adam, Kedudukan Sertifikasi Halal Dalam Sistem Hukum Nasional Sebagai Upaya Perlindungan Konsumen Dalam Hukum Islam,Amwaluna, Vol. 1 No. 1 , Januari, 2017, h.150

\section{Internet}

https://www.islampos.com/ylki-sumut-imbaumasyarakat-waspadai- peredaran-mi-instanmengandung-babi-53528/,diaksespada tanggal 2 Juli 2019, pukul 8.23 Wib.

https://id.wikipedia.org/wiki/LPPOM_MUI diakses pada tanggal 2 Juli $2019 \quad$ Pukul 11.00 Wib

https://www.republika.co.id/berita/koran/islamdigest-koran/14/08/10/na385a-definisihalal,diakses pada tanggal 8 Juli 2019 , Pukul 8.32 WIB.

http://nandurwit.com/peran-Ippom-mui-danbpjph-kemenag-dalam-sertifikasi-halal/, diakses pada tanggal 8 Juli 2019, Pukul 9.33 WIB.

https://kliklegal.com/empat-peran-Ippom-muidalam-proses-sertifikasi-halal-bersamabpjph/, diakses pada tanggal 8 Juli 2019, Pukul 9.34 WIB.

http://www.halalmui.org/images/stories/pdf/sjhindonesia.pdf, diakses pada tanggal 8 Juli 2019, Pukul 8.19 WIB.

https://news.detik.com/berita/d-4664936/taklagi-punya-otoritas-halal-mui-gugat-uujph-ke-mk diakses pada tanggal 1 November 2019, Pukul 13.24 WIB. 